\title{
APLIKASI ALAT PEMANAS KANDANG INDUKAN PADA BUDIDAYA AYAM RAS UNTUK MENINGKATKAN PENDAPATAN PETERNAK DI KECAMATAN LUMBUNG KABUPATEN CIAMIS
}

\author{
Heris Syamsuri*, Sri Solihah \\ Universitas Galuh \\ *Email: herissyamsuri@unigal.ac.id
}

\begin{abstract}
ABSTRAK
Program Pengabdian yang dikemas dalam paket kegiatan Aplikasi Alat Pemanas Kandang Indukan pada Budidaya Ayam Ras untuk Meningkatkan Pendapatan Peternak dilaksanakan di Kecamatan Lumbung Kabupaten Ciamis Propinsi Jawa Barat, bertujuan untuk mengatasi masalah tingginya konsumsi bahan bakar (LPG) pada masa pemeliharaan 1-15 hari pertama. Sedangkan target khusus yang ingin dicapai yaitu terbangunnya sistem pemanasan kandang idukan pada ayam ras yang didukung oleh alat pemanas yang hemat bahan bakar, khususnya para peternak ayam ras yang ada di Desa Rawa Kecamatan Lumbung Kabupaten Ciamis Metode yang digunakan dalam melaksanakan pengabdian ini yaitu metode instruksional yang diikuti dengan praktek dan pembuatan demplot. Tahapan kegiatan yang akan dilaksanakan meliputi empat tahapan, yaitu : Kegiatan pengabdian ini dibagi menjadi 4 (empat) tahapan, yaitu : tahap pertama penyampaian informasi teknologi pada para peternak melalui metode pembekalan dan instruksional, tahap kedua pendidikan dan pelatihan keterampilan bagi peternak pelaksana dan pengguna inovasi teknologi, tahap ketiga aplikasi percontohan (demplot) di lapangan pada tingkat peternak, dan tahap keempat kegiatan monitoring, evaluasi, pelaporan, dan seminar hasil kegiatan pengabdian. Partisipasi mitra dalam mendukung program pengabdian ini, selain sebagai peserta dalam pelatihan dan pelaksana demplot, juga ikut sharing dalam penyediaan alat dan bahan pembuatan demplot. Untuk pembuatan kandang indukan, penyediaan bibit ayam ras (DOC), pakan serta obat-obatan untuk budidaya ayam ras siap jual berbagi beban. Selain itu, peternak yang telah dilatih mempunyai tugas untuk menularkan teknologi yang telah dikuasainya kepada peternak lain, terutama masyarakat yang mempunyai minat untuk mengembangkan usaha pada budidaya ternak ayam ras.
\end{abstract}

Kata kunci: Ayam, Alat Pemanas, Kandang Indukan, hemat energi

\section{PENDAHULUAN}

Beternak ayam ras banyak dilakukan masyarakat yang berbisnis di bidang peternakan. Ayam ras mempunyai potensi yang besar terhadap pemenuhan kebutuhan konsumsi protein hewani masyarakat. Faktor-faktor yang berpengaruh terhadap produksi ayam ras yaitu sifat pertumbuhannya cepat, hal ini dikarenakan perbaikan genetik hasil pemuliabiakan serta didukung oleh factor lingkungan yang sesuai. Faktor genetik ini merupakan sifat dasar ayam ras yang diwariskan. Lingkungan adalah faktor eksternal yang bersifat biologis dan fisika langsung mempengaruhi kehidupan, pertumbuhan, dan reproduksi organisme.

Menurut data Badan Pusat Statistik (2015), terdapat peningkatan jumlah populasi unggas secara nasional pada tahun 2014 jika dibandingkan dengan tahun 2013 sebesar 7,38 \% yaitu sebanyak 1.443,35 juta ekor. Populasi ayam ras pada tahun 2015 sebanyak 1.497.625.658 ekor dan menghasilkan daging ayam seberat 1.627.107 ton.

Kegiatan berternak ayam ras ini cukup sederhana, namun banyak orang yang mempermasalahkan tentang bagaimana merawat anak ayam yang baru saja menetas dari telurnya. Anak ayam pada periode ini belum dapat mengatur temperatur tubuhnya sendiri. Pemeliharaan pada masa ini diperlukan kandang ayam yang dapat membuat anak ayam tetap 
Aplikasi Alat Pemanas Kandang Indukan pada Budidaya Ayam Ras Untuk Meningkatkan Pendapatan Peternak di Kecamatan Lumbung Kabupaten Ciamis

Heris Syamsuri, Sri Solihah

berada dalam keadaan nyaman. Temperatur nyaman pada ayam ras ketika masa brooding adalah sesuai dengan temperatur induknya yaitu $34^{\circ}-39^{\circ} \mathrm{C}$.

Ketika zona nyaman ini terpenuhi, maka pertumbuhan dan perkembangan anak ayam ras semakin cepat, hal ini akan mempercepat keuntungan peternaknya. Kebutuhan terhadap temperatur lingkungan dapat dipenuhi dengan menyediakan kandang indukan, yang merupakan serangkaian sistem yang terdiri atas alat pemanas (brooding) dan sekat yang dilengkapi tempat pakan, air minum, dan pencahayaan. Kelemahan alat pemanas yang digunakan peternak saat ini, yaitu biaya penggunaan bahan bakar (LPG) sangat tinggi. Berdasarkan hasil survey lapangan, untuk satu musim pemeliharaan, dengan kapasitas 500 ekor, menghabiskan bahan bakar LPG sebanyak 15-20 buah berkapasitas $12 \mathrm{~kg}$ atau sekitar Rp 2.700.000 s/d Rp 3.600.000. Sedangkan keuntungan yang diperoleh peternak untuk memelihara sebanyak 500 ekor ayam adalah Rp 458.716,33/periode (Nizam, 2013).

Salah satu terobosan untuk mengatasi hal tersebut adalah melalui penerapan hasil penelitian yang telah dilakukan penulis pada tahun akademik 2017/2018 dengan judul: Redesain Alat Pemanas Hemat Bahan Bakar untuk Kandang Indukan pada Budidaya Ayam Ras di Kecamatan Lumbung Kabupaten Ciamis Jabar yang dibiayai oleh Lembaga Pengabdian kepada masyarakat dan Pengabdian Kepada Masyarakat Universitas Galuh Tahun Anggaran 2017. Dari hasil penelitian sebelumnya telah dihasilkan sebuah produk alat pemanas yang memiliki beberapa keunggulan jika dibandingkan dengan alat pemanas yang saat ini digunakan peternak, yaitu: 1) Hemat bahan bakar (LPG) sebesar 20\% dan 2) Distribusi temperatur lebih merata

Ayam merupakan hewan unggas yang temperatur tubuhnya selalu dijaga tetap walaupun terjadi fluktuasi temperatur lingkungan di sekitarnya. Kenyamanan di dalam ruangan kandang dipengaruhi oleh temperatur udara, pergerakan udara dan kelembaban udara dan akan tergantung pada toleransi terhadap temperatur udara, pergerakan udara dan kelembaban udara di luar kandang (Sulistyoningsih: 2003).

Adapun tujuan dari pelaksanaan pengabdian kepada masyarakat ini adalah mengaplikasikan alat pemanas hasil penelitian pengusul yang berjudul: Re-desain Alat Pemanas Hemat Bahan Bakar untuk Kandang Indukan pada Budidaya Ayam Ras di Kecamatan Lumbung Kabupaten Ciamis Jabar yang dibiayai oleh Lembaga Pengabdian kepada masyarakat dan Pengabdian Kepada Masyarakat Universitas Galuh Tahun Anggaran 2018-2019. 


\section{ABDIMAS GALUH \\ Volume 1, Nomor 1, September 2019, 53-59}

\section{BAHAN DAN METODE}

Khalayak sararan pelaksanaan pengabdian kepada masyarakat ini adalah para peternak ayam ras di Kecamatan Lumbung. Sehubungan dengan keterbatasan waktu dan pendanaan maka dalam pengabdian ini dilakukan prinsip tutor sebaya yaitu dengan cara melatih beberapa perwakilan dari peternak, dan selanjutnya peternak yang telah dilatih tersebut ditugaskan untuk menyebarluarkan pengetahuan yang diperolehnya kepada para peternak lainnya.

Metode yang digunakan dalam melaksanakan pengabdian ini yaitu metode instruksional yang diikuti dengan praktek dan pembuatan demplot. Hasil dari pelaksanaan demplot dievaluasi tingkat keberhasilannya dan dianalisis kelayakan ekonomisnya sebagai bahan laporan. Sebagai hasil akhir dari kegiatan ini yaitu dilaksanakan seminar.

Pengabdian yang dikemas dalam paket kegiatan "Pembuatan Demplot Aplikasi Penerapan Teknologi Alat Pemanas untuk Kandang Indukan pada Budidaya Ayam ras yang dilaksanakan pada peternak ayam ras di Desa Rawa Kecamatan Lumbung Kabupten Ciamis Jawa Barat.

Kegiatan pengabdian ini dibagi menjadi 4 (empat) tahapan, yaitu: tahap pertama penyampaian informasi teknologi pada para peternak melalui metode pembekalan dan instruksional, tahap kedua pendidikan dan pelatihan keterampilan bagi peternak pelaksana dan pengguna inovasi teknologi, tahap ketiga aplikasi percontohan (demplot) di lapangan pada tingkat peternak, dan tahap keempat kegiatan monitoring, evaluasi, pelaporan, dan seminar hasil kegiatan pengabdian.

Tahap I

Pada tahap ini dilaksanakan berupa penyampaian informasi teknologi yaitu sosialisasi atau penyuluhan kepada para peternak ayam ras dan perwakilan masyarakat. Materi yang diberikan meliputi: 1) materi umum yaitu budidaya ayam ras. 2) materi khusus berupa: komparasi alat pemanas pabrikan dengan alat pemanas hasil re-desain, dan 3) materi penunjang berupa analisis ekonomi terhadap penerapan alat pemanas hasil rancangan. Hasil yang diharapkan dari kegiatan ini, yaitu para peternak ayam ras mengetahui manfaat dan kelebihan dari penerapan alat pemanas, sehingga mau mengadopsi teknologi alat pemanas tersebut.

Tahap II

Pada tahap ini kegiatan yang dilaksanakan yaitu pelatihan keterampilan dalam penerapan alat pemanas untuk kandang indukan pada budidaya ayam ras, dengan beberapa keterampilan yang dilatihkan meliputi: 1) Pembuatan kandang indukan, 2) Perakitan alat pemanas dan penggunaannya. 
Aplikasi Alat Pemanas Kandang Indukan pada Budidaya Ayam Ras Untuk Meningkatkan Pendapatan Peternak di Kecamatan Lumbung Kabupaten Ciamis

Heris Syamsuri, Sri Solihah

Peserta pelatihan yaitu peternak yang berada di Desa Rawa Kecamatan Lumbung Kabupaten Ciamis sebanyak 4 peternak. Kegiatan ini diawali penyuluhan tatap muka, yaitu penjelasan mengenai alat pemanas antara pabrikan dan hasil re-desain, pengenalan alat dan bahan yang digunakan untuk kandang indukan, kemudian dilanjutkan dengan praktek pembuatan dan penggunaannya. Hasil yang diharapkan dari kegiatan ini, yaitu para peternak mampu menggunakan dan mampu membuat kandang indukan yang memenuhi persyaratan teknis pada budidaya ayam ras, serta mampu menjadi tutor sebaya terhadap peternak lainnya. Tahap III

Kegiatan pada tahap ini berupa aplikasi teknologi di lapangan, yaitu dengan membuat demplot atau percontohan untuk mengaplikasikan alat pemanas pada kandang indukan yang meliputi: 1) Percontohan budidaya ayam buras dengan menggunakan alat pemanas yang hemat energi untuk menunjang dan mempermudah aplikasi teknologi alat pemanas untuk kandang indukan. Demplot budidaya ayam ras dibuat untuk kapasitas 250 ekor anak ayam (DOC), dan 2) Percontohan budidaya ayam ras ini dilaksanakan oleh 4 (empat) orang peternak yang telah dilatih.

\section{Tahap IV}

Pada tahap ini dilaksanakan kegiatan sebagai berikut: pengamatan/monitoring terhadap aplikasi alat pemanas kandang indukan pada budidaya ayam ras oleh para peternak yang telah dilatih, serta melakukan evaluasi terhadap hasil dari monitoring tersebut. Langkah selanjutnya membuat laporan sebagai bahan pelaporan dari serangkaian kegiatan pengabdian yang telah dilaksanakan. Sebagai akhir dari kegiatan ini dilaksanakan seminar hasil pengabdian.

Partisipasi mitra dalam mendukung program ini, selain sebagai peserta dalam pelatihan dan pelaksana demplot, juga ikut sharing dalam penyediaan alat dan bahan pembuatan demplot. Untuk pembuatan kandang indukan, penyediaan bibit ayam ras (DOC), pakan serta obat-obatan untuk budidaya ayam ras siap jual berbagi beban. Selain itu, peternak yang telah dilatih mempunyai tugas untuk menularkan teknologi yang telah dikuasainya kepada peternak lain, terutama masyarakat yang mempunyai minat untuk mengembangkan usaha pada budidaya ternak ayam ras.

\section{HASIL DAN PEMBAHASAN}

Meskipun kegiatan berternak ini cukup sederhana, banyak peternak di kecamatan Lumbung mempermasalahkan tentang bagaimana merawat anak ayam yang baru saja menetas, karena anak ayam pada periode ini belum bisa mengatur suhu tubuhnya sendiri. 
Untuk itu perlu kandang ayam yang dapat membuat anak ayam tersebut tetap berada di dalam keadaan zona nyaman yaitu pada ayam broiler ketika masa brooding.

Masa brooding adalah masa dimana anak ayam masih butuh indukan atau butuh penghangat buatan sampai umur tertentu yaitu sampai anak ayam bisa menyesuaikan sendiri dengan suhu lingkungannya. Untuk ayam broiler masa broodingnya yaitu selama 15 hari. Suhu yang diperlukan disesuaikan dengan suhu tubuh induk ayam yaitu $35^{\circ} \mathrm{C}-39^{\circ} \mathrm{C}$.

Kebutuhan terhadap temperatur ini dapat dipenuhi dengan menyediakan kandang indukan, yang merupakan serangkaian sistem yang terdiri dari alat pemanas (brooding) dan sekat yang dilengkapi tempat pakan dan air minum, dan pencahayaan.

Pada tahap ini dilaksanakan pelatihan keterampilan dan penerapan alat pemanas untuk kandang indukan pada budidaya ayam ras, yaitu pembuatan kandang indukan, Kandang indukan yang digunakan sebagai zona pengamatan adalah kandang milik peternak dengan ukuran $\mathrm{p} \times 1 \times \mathrm{t}$ adalah $12 \mathrm{~m} \times 3 \mathrm{~m} \times 2,5 \mathrm{~m}$, yang disekat menjadi ukuran $\mathrm{p} \times 1 \times \mathrm{t}=4 \mathrm{~m} \times 3 \mathrm{~m}$ x 2,5 m diperlihatkan pada Gambar 1 .

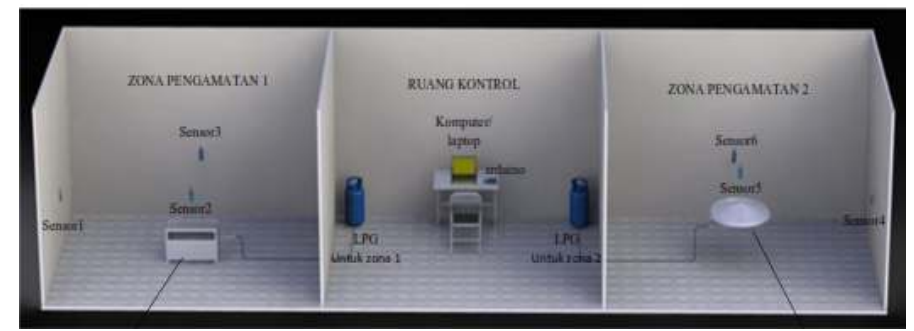

Gambar 1. Gambar Kandang Indukan

a. Desain Alat Pemanas

Dalam pengabdian kepada masyarakat ini diawali memprkenalkan hasil desain alat pemanas yang akan digunakan peternak. Desain dilakukan untuk menghasilkan alat yang: 1) Konsumsi bahan bakar harus lebih hemat dari pemanas saat ini, 2) Mudah dioperasikan, dan 3) Mempunyai tingkat keamanan yang lebih handal.

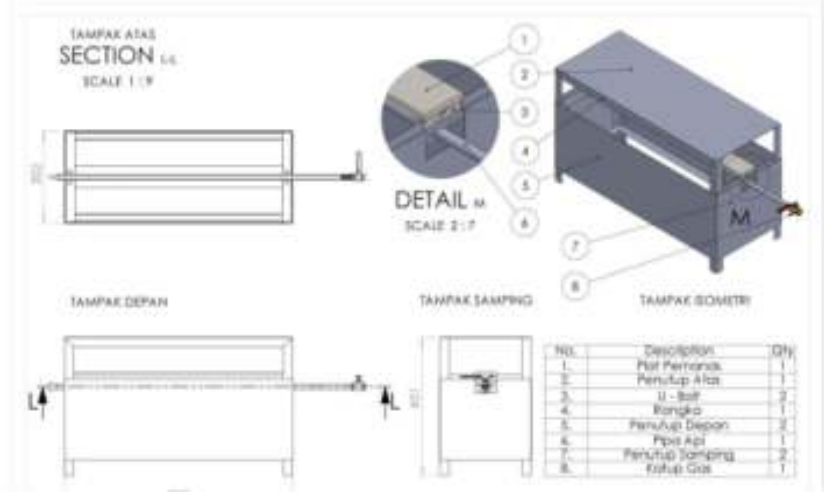

Gambar 2. Hasil Desain Alat Pemanas 
Aplikasi Alat Pemanas Kandang Indukan pada Budidaya Ayam Ras Untuk Meningkatkan Pendapatan Peternak di Kecamatan Lumbung Kabupaten Ciamis

Heris Syamsuri, Sri Solihah

\section{b. Proses Pembuatan Alat}

Setelah desain alat pemanas disosialisasikan, selanjutnya dilakukan pelatihan proses perakitan, yaitu memperkenalkan alat yang digunakan dalam proses perakitan ini adalah sebagai berikut:

\begin{tabular}{|c|c|c|c|}
\hline No & $\begin{array}{c}\text { Nama } \\
\text { Alat }\end{array}$ & Fungsi & Gambar \\
\hline 1 & Meteran & $\begin{array}{l}\text { Meteran digunakan } \\
\text { untuk mengukur } \\
\text { panjang, lebar dan tinggi } \\
\text { besi siku yang akan } \\
\text { dibuat menjadi rangka } \\
\text { pemanas, dll }\end{array}$ & \\
\hline 2 & $\begin{array}{l}\text { Mesin } \\
\text { Gerinda }\end{array}$ & $\begin{array}{l}\text { Mesin gerinda } \\
\text { digunakan untuk } \\
\text { pemotongan dan } \\
\text { penghalusan komponen- } \\
\text { komponen mesin } \\
\text { pemanas baik dari } \\
\text { rangka, plat penutup atas }\end{array}$ & \\
\hline 3 & $\begin{array}{c}\text { Mesin } \\
\text { Bor }\end{array}$ & $\begin{array}{l}\text { digunakan untuk } \\
\text { membuat lubang pada } \\
\text { mesin pemanas misalnya } \\
\text { pembuatan lubang pada } \\
\text { plat safety atas yang } \\
\text { berfungsi sebagai tempat } \\
\text { penahan panas }\end{array}$ & \\
\hline 4 & $\begin{array}{l}\text { Jangka } \\
\text { Sorong }\end{array}$ & $\begin{array}{l}\text { Jangka sorong } \\
\text { digunakan untuk } \\
\text { mengukur dimensi alat } \\
\text { pemanas }\end{array}$ & \\
\hline 5 & $\begin{array}{l}\text { Gunting } \\
\text { seng }\end{array}$ & $\begin{array}{l}\text { Gunting seng digunakan } \\
\text { untuk memotong } \\
\text { penutup samping alat } \\
\text { pemanas. }\end{array}$ & \\
\hline 6 & Seal tape & $\begin{array}{l}\text { Seal tape digunakan } \\
\text { untuk mencegah } \\
\text { kebocoran pada } \\
\text { sambungan pipa api dan } \\
\text { kran. }\end{array}$ & \\
\hline
\end{tabular}

Gambar 3. Peralatan yang diperlukan dalam proses perakitan

\section{KESIMPULAN DAN SARAN}

\section{Kesimpulan}

Pada pelaksanaan pengabdian kepada masyarakat yang telah dilakukan diperoleh halhal sebagai berikut:

1. Peternak ayam ras mengetahui manfaat dan kelebihan dari alat pemanas, sehingga mau mengadopsi teknologi alat pemanas hasil penelitian pengusul.

2. Peternak mampu menggunakan dan mampu membuat kandang indukan yang memenuhi persyaratan teknis pada budidaya ayam ras, serta mampu menjadi tutor sebaya terhadap peternak lainnya. 
3. Peternak mampu mengaplikasikan budidaya yang didukung penerapan teknologi alat pemanas kandang indukan, sehingga dapat menurunkan tingkat stress pada ayam dan meningkatkan konversi pakan terhadap bobot ayam secara optimal.

\section{Saran}

Peternak ayam ras di desa Rawa Kecamatan Lumbung Kabupaten Ciamis, potensial untuk dikembangkan lebih lanjut. Hal ini terlihat dari potensi masyarakatnya yang telah turun temurun memelihara ayam, selain itu pemasaran ayam sudah sangat luas mencakup luar kabupaten Ciamis, bahkan luar Provinsi Jawa Barat.

Perlu dilakukan segera, pelatihan terkait keterampilan peternak agar hasil budidaya ayam bisa dipasarkan dalam bentuk makanan olahan.

\section{DAFTAR PUSTAKA}

Anwar Kholidi, dkk, (2015). Rancang Bangun Alat Pemberi Pakan dan Pengatur Temperatur Otomatis untuk Ayam Pedaging Berbasis Programmable Logic Controller pada Kandang Tertutup. Jurnal Rekayasa dan Teknologi Elektro “Elektrian” Vol 9 No. 2.

Dede Risnajati. (2011). Pengaruh Jenis Alat Pemanas Kandang Indukan Terhadap Performan Layer Periode Starter. Sains Peternakan Vol. 9(1):20-24, ISSN 1693-8828.

Fajrin Sidiq dan Wira Wisnu Wardani, (2014). Strategi Menghadapi Cekaman Panas pada Industri Unggas Modern, Masterlab Asia and Trouw Nutrition Indonesia, Bekasi Indonesia.

Gunawan dan D.T.H. Shihombing, (2011), Pengaruh Temperatur Lingkungan Tinggi terhadap Kondisi Fisiologis dan produktivitas Ayam Buras. Wartazoa Vol.14 No. 01. Indonesia

H.E.T. Ruseffendi, (1993). Statistik Dasar untuk Pengabdian kepada Masyarakat. Direktorat Pendidikan dan Kebudayaan, Direktorat Jendral Pendidikan Tinggi, Proyek Pembinaan Tenaga Kependidikan Pendidikan Tinggi, Jakarta.

Heris Syamsuri, (2015). Re-desain Canting Listrik untuk Meningkatkan Produktivitas Industri Batik Ciamisan, Pengabdian kepada masyarakat Dosen. LPPM Universitas Galuh.

Imam Ismail, dkk, (2013). Analisa ekonomi usaha peternakan broiler yang menggunakan dua tipe kandang berbeda. Jurnal Ilmu-ilmu Peternakan 23(3): 11-16. ISSN : 0852-3581.

Mei Sulistyoningsih, (2003), Pengaruh temperatur lingkungan terhadap ayambroiler, Majalah Ilmiah Lontar, Vol. 17 No. 01, Semarang.

Mohammad Hasil Tamzil, (2014), Stres Panas pada Unggas: Metabolisme, Akibatdan Upaya Penanggulangannya, Wartazoa Vol.24 No. 02. Indonesia.

Mufid Dahlan dan Nur Hudi, (2011). Studi Manajemen Perkandangan Ayam Broilerdi Dusun Wangket Desa Kaliwates Kecamatan Kembangbahu Lamongan. Jurnal Ternak, Vol. 02 No. 01. Indonesia.

Sahrudin. dkk, (2012), Performa Ayam Ras Pedaging terhadap Pembatasan Waktu Aksesibilitas Pakan, Program Pascasarjana, Ilmu Peternakan Universitas.

Hasanudin, Makasar. Sonty Lena, (2014). Perancangan dan implementasi Pemantau Temperatur sertaPenanganan Dini Kandang Ayam Broiler Berbasis Mikrokontrol, Jurnal LPKIA, Vol. 1 No. 1. Indonesia. 